(C) 2013

Паска М. 3., кандидат ветеринарних наук

Львівський Національний університет ветеринарної медицини та біотехнологій імені С. З. Гжицького

\title{
ВМІСТ СУЛЬФГІДРИЛЬНИХ ГРУП ТА ГЛУТАТІОНУ В БУГАЙЩІВ ВОЛИНСЬКОЇ М'ЯСНОЇ ПОРОДИ РІЗНИХ ТИПІВ ВИЩОЇ НЕРВОВОЇ ДІЯЛЬНОСТІ ЗА ДІЇ БІОЛОГІЧНО АКТИВНИХ РЕЧОВИН
}

\section{Рецензент - доктор ветеринарних наук І. Д. Юськів}

\begin{tabular}{|} 
Встановлено залежність вмісту сульфгідрильних \\
груп, загального, відновленого та окисненого глу- \\
татіону від типу вищої нервової діяльності у \\
бугайців на відгодівлі волинської м'ясної породи. \\
Найвищими показниками сульфгідрильних груп, \\
загального, відновленого та окисненого глутатіону \\
характеризувалися тварини сильного врівноваже- \\
ного інертного типу. Актуальність досліджень \\
зумовлена вивченням даного питання в бугайців на \\
відгодівлі волинської м'ясної породи різних типів \\
вищої нервової діяльності в разі додавання до \\
раціону рослинно-вітамінно-мінеральної добавки \\
«Мікровітоліп».
\end{tabular}

Ключові слова: фізіологія, сульфгідрильні групи, глутатіон, бугайщі, вища нервова діяльність, волинська м'ясна порода, відгодівля.

Постановка проблеми. В останні роки ученими встановлена роль сульфгідрильних сполук та глутатіону в процесах метаболізму. Проте питання їхнього вмісту у бугайців волинської м'ясної породи різних типів вищої нервової діяльності за дії біологічно-активних речовин вивчено не повністю, що становить наукову новизну нашої роботи.

Аналіз останніх досліджень i публікацій, у яких започатковано розв'язання проблеми. Функціональні SH-групи білків складають невід'ємну частину біокаталітичної системи живого організму. Поряд із виконанням своєї функції у ферментах сульфгідрильні групи проявляють вплив на різні фізіолого-біохімічні процеси [1]. Глутатіон (завдяки наявності реактивної сульфгідрильної групи) вступає у біохімічні реакції метаболізму, забезпечує нормальне проходження певних життєво важливих процесів. До того ж відновлена форма глутатіону стимулює ріст, а окиснена, навпаки, сповільнює. Крім того, глутатіон - основний антиоксидант у водній фазі клітин. Антиоксидантні властивості глутатіону визначаються як безпосередньою взаємодією 3 АФК і реакціями обміну речовин із дисульфідними зв'язками, так і функціонуванням низки ферментів глутатіонового циклу, основними 3 яких $€$ глутатіонпероксидаза та глутатіон-Sтрансфераза [4].

Одна 3 основних антиоксидантних функцій глутатіону полягає у відновленні метгемоглобіну: на частку глутатіону припадає близько $12 \%$ метгемоглобінвідновлюючої здатності клітини. 3 клітин еритроїдного ряду вищий рівень глутатіону відмічений у ретикулоцитах: до того ж швидкість його відновлення в цих клітинах у 620 разів вища, ніж у зрілих еритроцитах. Відновлення глутатіону відбувається за допомогою ферменту глутатіонредуктази, а також через

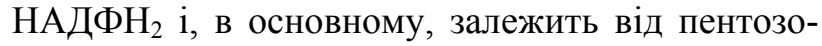
фосфатного шунта [1].

Мета і завдання досліджень. Метою роботи було вивчення вмісту сульфгідрильних груп, загального глутатіону, його окисненої та відновленої форм у бугайців різних типів вищої нервової діяльності волинської м'ясної породи за дії біологічно-активних речовин.

До завдань входило: визначити типи ВНД у бугайців; додати до раціону рослинно-вітамінномінеральну добавку «Мікровітоліп» та визначити показники вмісту сульфгідрильних груп і глутатіону в плазмі крові.

Матеріал і методи дослідження. Дослідження проводили в ТОВ «Агрофірма «Добросин»»» Жовківського району Львівської області на бугайцях м'ясного напряму продуктивності початкового періоду відгодівлі у віці 6 місяців.

Типи вищої нервової діяльності (ВНД) у бугайців визначали, застосовуючи позакамерну методику вироблення рухово-харчових умовних рефлексів А. С. Макарова (1968) [3].

На основі проведених досліджень умовнорефлекторної діяльності 80-ти бугайців сформовано чотири дослідні групи тварин, по десять найтиповіших представників визначених типів ВНД у кожній:

- перша група - тварини сильного врівноваженого рухливого (СВР) типу ВНД;

- друга група - тварини сильного врівноваженого інертного (CBI) типу ВНД; 
- третя група - тварини сильного неврівноваженого (СН) типу ВНД;

- четверта група - тварини слабкого (C) типу ВНД.

Тварини всіх груп отримували основний раціон, у якому частину зернової основи раціону заміняли $5 \%$ рослинно-вітамінно-мінеральної добавки «Мікровітоліп».

У плазмі крові визначали: концентрацію вільних сульфгідрильних груп білків методом амперометричного титрування за В. В. Соколовським [5]; вміст загального глутатіону, його окисненої та відновленої форм - за методикою Вудварда i Фрея мікрометодом у модифікації М. С. Чулкової (1955) [6];

Результати дослідження. У процесі вивчення вмісту сульфгідрильних груп встановлено зміни показника залежно від типу вищої нервової діяльності [2, 4]. Так, мінімальне значення показника виявлено у тварин слабкого типу. Найвища концентрація сульфгідрильних груп виявлена у тварин сильного врівноваженого інертного типу - 564,2 $\pm 9,8$ мкмоль/л, що більше на 17,1 $(\mathrm{p}<0,01), 14,8(\mathrm{p}<0,05)$ та 7,8 \% більше, порівняно 3 тваринами $\mathrm{C}, \mathrm{CH}$, та СВР типів ВНД.

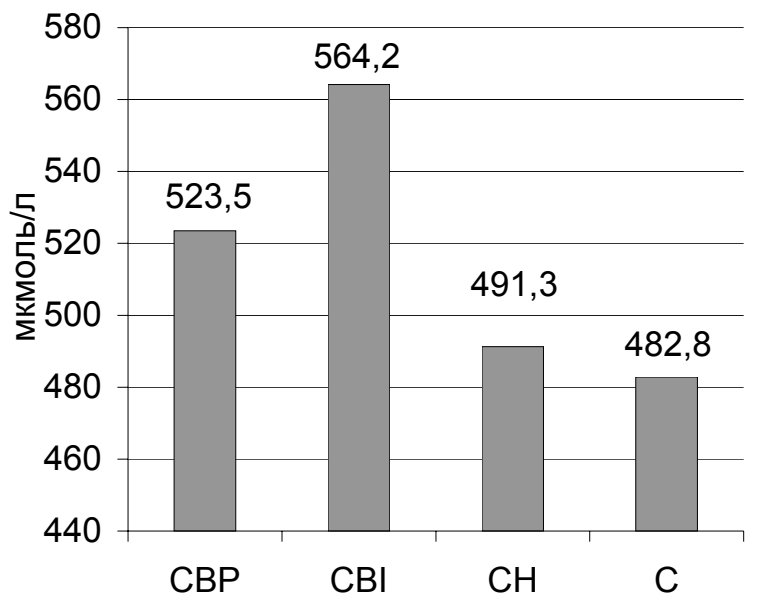

\section{Puc. 1. Вміст SH-груп у сироватці крові бугайців волинської м'ясної породи різних типів ВНД}

Зокрема, SH-вмісним сполукам належить провідна роль у захисті клітин від радикалу $\mathrm{OH}^{\bullet}$, що утворюється в реакції Фентона чи в результаті розкладання $\mathrm{H}_{2} \mathrm{O}$ під дією іонізуючого випромінювання. Поскільки малі значення часу життя й радіуса дифузії $\mathrm{OH}^{*}$ у біологічних субстратах роблять неможливим існування спеціалізованих протективних систем, подібних супероксиддисмутазі чи каталазі. Відзначено, що SH-вмісні сполуки піддаються окисненню в першу чергу. Це оберігає від окиснення інші функціональні
Зокрема, SH-вмісним сполукам належить провідна роль у захисті клітин від радикалу ОН•, що утворюється в реакції Фентона чи в результаті розкладання $\mathrm{H}_{2} \mathrm{O}$ під дією іонізуючого випромінювання. Поскільки малі значення часу життя й радіуса дифузії ОН• у біологічних субстратах роблять неможливим існування спеціалізованих протективних систем, подібних супероксиддисмутазі чи каталазі. Відзначено, що SH-вмісні сполуки піддаються окисненню в першу чергу. Це оберігає від окиснення інші функціональні групи та молекули. На SH-групи білків припадає близько $50 \%$ інгібування $\mathrm{O}_{2}^{1}, \mathrm{HOCl}$ та процесів ПОЛ у крові [7]. Крім того, тіолові сполуки важливі компоненти підтримання окисновідновного гомеостазу у клітинах i тканинах. За різних стресових впливах і патологічних станах виявлена зворотна окиснювальна модифікація SH-груп, яка призводить до збільшення кількості дисульфідних груп, що $є$ неспецифічною реакцією організму на екстремальний вплив. Така модифікація змінює стан клітинних мембран, їх проникність і адгезивні властивості, впливає на активність ферментів і клітинну проліферацію. Власне тому співвідношення відновлених i окиснених SH-груп та їх здатність до окиснювальної модифікації (буферна ємність) служать важливими критеріями неспецифічної резистентності організму [1].

Аналізуючи вміст загального глутатіону встановлено, що він був найвищим у тварин CBI типу i становив 54,2 $\pm 1,9$ мг/100 мл; це більше на 8,1\% $(\mathrm{p}<0,05), 12,2(\mathrm{p}<0,05)$ та 20,2 (p<0,001) порівняно 3 тваринами СВР, СН та С типів (рис. 2).

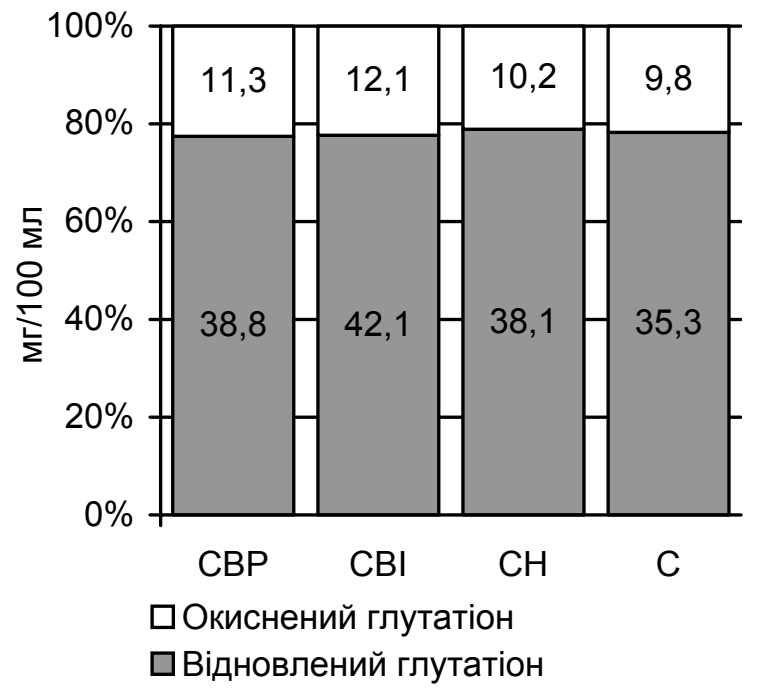

Рис. 2. Вміст глутатіону в крові бугайців на відгодівлі волинської м'ясної породи різних типів ВНД 
За фізіологічних умов в організмі зберігається постійна рівновага між швидкістю процесів ПОЛ та активністю антиоксидантної системи. Збільшення продуктивності тварин супроводжується активацією окисно-відновних процесів. Про деяку активність антиоксидантних систем організму можна судити за концентрацією глутатіону, що відіграє роль резерву цистеїну. Водночас глутатіон $є$ інгібітором активних форм кисню та стабілізатором мембран [1].

Глутатіоновий статус тканин окрім того відіграє важливу роль у багатьох процесах, зокрема, за гіпероксичних станів. Коли концентрація $\mathrm{O}_{2}$ в системі є нижчою, ніж уміст глутатіону, відбувається обрив ланцюгів і регенерація радикалів у початкову молекулу RH. Проте в разі зміни концентраційного співвідношення $\mathrm{O}_{2}$ і глутатіону в іншу сторону - розвивається ланцюгова реакція окиснення, а глутатіон виступає лише в якості обмежувача вільнорадикального окиснення [7].

У ході вивчення вмісту відновленого глутатіону встановлено, що в тварин дослідних груп він становив $38,8 \pm 1,1 ; 42,1 \pm 1,4 ; 38,1 \pm 1,1$ та $35,3 \pm 1,0$ мг/100 мл (рис. 2 ).

Аналізуючи вміст окисненого глутатіону у бугайців дослідних груп варто відзначити: його найвища концентрація встановлена у тварин СВI типу, що, відповідно, на 7,1; 18,6 та 23,5\% $(\mathrm{p}<0,001)$ більше, порівняно 3 тваринами СВР, $\mathrm{CH}$ та С типів (рис. 2).

Роль глутатіону не обмежується формуванням основного низькомолекулярного антиоксидантного потенціалу еритроцитів і кровотворних клі-

\section{БІБЛІОГРАФІЯ}

1. Величко B. Корекція антиоксидантного статусу сільськогосподарських тварин мікроелементами. - Львів : Сполом. - 76 с.

2. Карповський В. І. Активність а-амілази в сироватці крові корів залежно від типу вищої нервової діяльності / В. І. Карповський, Д. І. Криворучко, В. О. Постой Р. В. [та ін.] // Науковий вісник Луганського національного аграрного університету - Л. : НАУ, 2012. - С. 51-54.

3. Макаров А. С. Методическое пособие по определению наличных типов высшей нервной деятельности у крупного рогатого скота внекамерным методом. - Казань, 1968. - 30 с.

4. Паска М. 3. Біохімічні показники крові бугайців волинської м'ясної породи залежно від типів тин, що дає змогу протистояти гемоглобін- i ферментзалежній генерації АФК. Окрім того клітинний глутатіон бере участь у підтримці пулу відновленого аскорбату - антиоксиданту, який здійснює захист елементів системи крові ззовні.

Отже, на основі проведених досліджень можна зробити висновок, що бугайці сильного врівноваженого інертного типу, порівняно з іншими групами, мають вищі концентрації сульфгідрильних груп, відновленого окисненого та загального глутатіону в разі додавання до раціону рослинно-вітамінно-мінеральної добавки «Мікровітоліп».

\section{Висновки:}

1. Встановлено залежність вмісту сульфгідрильних груп, відновленого, окисненого та загального глутатіону від типу ВНД у бугайців на відгодівлі волинської м'ясної породи при додаванні до раціону рослинно-вітамінно-мінеральної добавки «Мікровітоліп» .

2. Найвищими показниками вмісту сульфгідрильних груп та глутатіону характеризувалися тварини сильного врівноваженого інертного типу за додавання до раціону рослинно-вітамінномінеральної добавки «Мікровітоліп».

3. Отримані результати досліджень будуть застосовані у подальшому вивченні активності системи АОЗ-ПОЛ бугайців волинської м'ясної породи на відгодівлі при додаванні до раціону рослинно-вітамінно-мінеральної добавки «Мікровітоліп», залежно від типу ВНД та їі вплив на формування м’ясної продуктивності тварин.

вищої нервової діяльності / Науково-технічний бюлетень // Вип. 13, № 1-2. - Львів, 2012. С. 113-120.

5. Соколовский В. В. Определение содержания сульфгидрильных групп в крови амперометрическим титрированием // Лаб. дело. - 1965. №8. - С. 399-402.

6. Травина О.В. Руководство по биохимическим исследованиям. - М. : Медгиз, 1955. - С. 250-255.

7. Утворення активних форм кисню та система антиоксидантного захисту в організмі тварин / Г. Л. Антоняк, Н. О. Бабич, Л. І. Сологуб [та ін.] // Біологія тварин. - 2000. - Т. 2, №2. - С. 34-43. 